\title{
STUDIES ON THE MECHANISM OF SALT AND WATER SECRETION FROM THE LACRIMAL GLAND
}

\author{
Hisato Yoshimura and Keimei Hosokawa* \\ Department of Physiology Kyoto, Prefectural University of Medicine
}

Up to the present time, not many studies have been reported on the mechanism of salt and water secretion from the lacrimal gland. The most outstanding works among them are those performed by Denmark School ${ }^{11}$. KROGH, Lund and Pedersen-BJerdaARD ${ }^{2)}$ first demonstrated with human eyes that the tears are isotonic with extracellular fluid and contain sodium in a concentration equal to that of plasma. Later, THAYSEN and THORN ${ }^{3)}$ confirmed these findings; and further, they found that the concentrations of sodium, potassium and chloride in the tears are independent of a wide range of variation in the rate of tear secretion; and that the concentrations of $\mathrm{K}$ and $\mathrm{Cl}$ in the tears are higher than those in the plasma. In their experiments, the rate of tear flow was measured by weighing the cotton pieces which had been placed in the conjunctival sac of the subject and had absorbed the tears for an interval of a certain time. Thus, this measurement of rate of tear flow is inexact. In the present experiments, the authors attempted to observe the ionic concentrations in the tear fluid with special reference to the rate of tear flow, measuring it more accurately by using rabbits' lacrimal glands as the experimental target, and to clarify the mechanism of tear secretion by measuring the secretion potential of the gland with due reference to the ionic concentration and the rate of tear flow.

\section{METHODS}

Rabbits (weighing $2.2-3.4 \mathrm{Kg}$ ) were fixed without anesthesia, and the excretion of tears was provoked by subcutaneous injection of $1 \%$ pilocarpine $5 \mathrm{ml} / \mathrm{Kg}$. With the tears produced experiments were performed in the following three stages: (1) Measurements of ionic constituents, and osmotic pressure of tears with due reference to the rate of tear flow. (2) Observations of the relation between ionic concentration of serum and that of tears, especially after intravenous infusion of salt solution. (3) Measurements of secretion potential of the gland with special reference to the rate of lacrimal flow.

Received for publication March 4, 1933.

* 吉村寿人, 細川計明 
To collect the tears, a capillary pipette was inserted into a tear fistula, which had been made on one of the eyes several days prior to the experiments. Then the rate of flow was measured by reading the marks on the capillary pipette.

Measurements of secretion potential were made with a vacuum tube potentiometer by leading the potential externally from tube type indifferent electrodes, one of which was inserted into the conjunctival sac and the other under the subcutaneous tissue of the eye lid. The procedures are as follows:

The tear fistula: One of the rabbit eyes was anesthetised locally with $4 \%$ xylocain; a fine bougie was inserted into the naso-lacrimal duct and the bore of duct was gradually expanded. A vinyl capillary tube of $2 \mathrm{~mm}$ bore and $5 \mathrm{~cm}$ length was connected to the bougie, which was inserted into the duct. At the spot where the end of the bougie hit the distal part of the duct, the skin was incised and the tip of the inserted vinyl capillary was pulled out from the duct and was connected to a graded capillary pipette. The other end of the vinyl capillary, having been inflated with heat, prevented the capillary from falling out of the lacrimal duct. Finally, the eye lids and the incised skin were sutured, and thus the conjunctival sac was closed so as to prevent any evaporation of the tears; and the lacrimal fistula was fixed to the nasolacrimal duct thereby leading the tears into the pipette. By reading the amount of tears in the pipette per unit time, the rate of tear flow was estimated.

The collection of blood and tears: The blood was collected from the central vein of ear or from a cannula inserted into the femoral artery. The volume of collected blood was $1 \mathrm{ml}$ or so, and was centrifuged immediately under a heavy liquid paraffine layer. The specific gravity and ionic constituents of serum were measured as soon as possible after separation of serum.

The saline solution was also infused through the cannula of the femoral vein. The blood was collected immediately prior to and one hour after the infusion, and the change in salt concentration in serum after the salt infusion was determined. The salt solutions infused were $10 \% \mathrm{NaCl}$ solution and $4 \% \mathrm{KCl}$ solution.

Measurement of secretion potential: To lead the potential from the tissue, two indifferent electrodes were constructed with the $\mathrm{Ag}-\mathrm{Ag} \mathrm{Cl}$ electrode which was dipped into a small glass tube containing physiological saline. The glass tube was connected to a vinyl tube and then to another glass tube which ends in a fine sharp capillary. All being filled with the physiological saline, the end of one electrode was inserted into the upper part of the closed conjunctival sac and the sharp capillary of another electrode was inserted into the subcutaneous tissue of the upper lid. The $\mathrm{Ag}-\mathrm{Ag} \mathrm{Cl}$ electrodes of the two indifferent electrodes were connected with copper wire to a vacuum tube potentiometer of SHimazu GM-1 type, and the potential between the lumen of the lacrimal gland and the tissues outside of the gland was measured. The measurement was made before the injection of pilocarpine, and the potential thus measured corresponded to the resting potential of the lacrimal gland. After the injection of pilocarpine solution the potential was measured with an interval of 5 minutes. The change of potential from the resting level corresponds to the secretion potential.

Measurements of ionic constituents: $\mathrm{Na}$ and $\mathrm{K}$ concentrations in tear and serum were measured with LANGE's flame photometer, and $\mathrm{Cl}$ concentration by SHALES and SHAles method. The specific gravity of serum was measured by copper sulphate method and from this the water content of serum was calculated. The ionic concentrations in serum are expressed in concentration in serum water except otherwise stated. The $\mathrm{pH}$ was measured with Yoshimura-HosokawA's microcapillary electroded), and $\mathrm{CO}_{2}$ with Kopp-Natelson's microgas analyser ${ }^{5}$. The bicarbonate concentration was calculated by aid of HeNDERSON-HASSELBALCH's equation, assuming pK to be 6.10 in serum as well as in tears at $37^{\circ} \mathrm{C}$ as the tears were found to be isotonic. Osmolar 
concentration in tears and serum were determined by measuring the freezing-point depression with Yoshimura-URAGAmI's micro-thermister thermometer ${ }^{6)}$.

\section{EXPERIMENTAL RESULTS}

1. Ionic constituents of tears in relation with the rate of tear flow. An example of the results of measurements of ionic constituents of tears is illustrated in FIG. 1, in which concentrations of $\mathrm{Na}^{+}, \mathrm{Cl}^{-}, \mathrm{K}^{+}$and $\mathrm{HCO}_{3}^{-}$and $\mathrm{pH}$ in tears

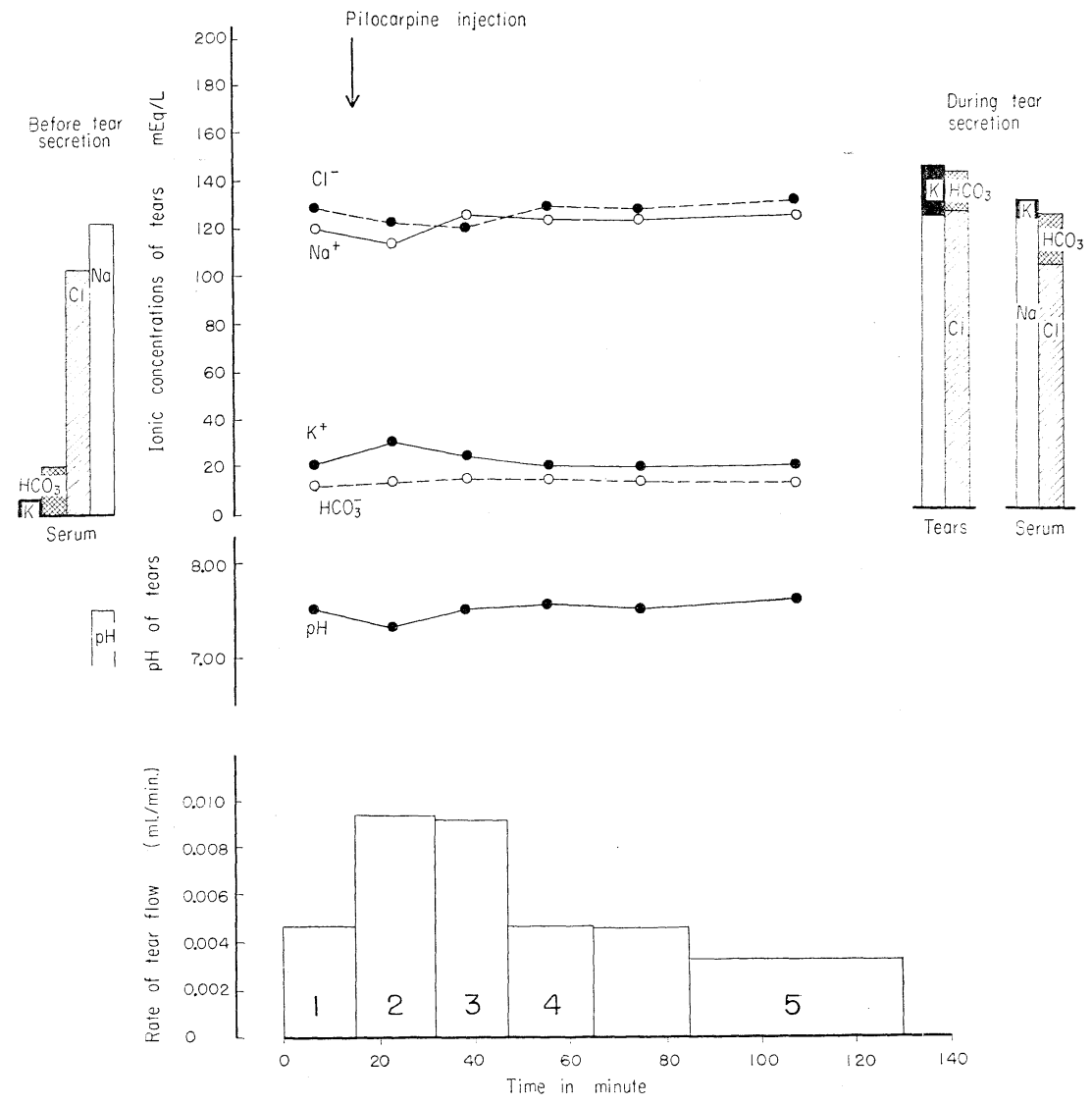

FIG. 1. Rate of tear flow and ionic concentrations in tears and in serum.

collected every 20 minutes after pilocarpine injection, are given in sequence of collection time. The ionic constituents of serum which were collected from ear vein just before the pilocarpine injection, are also given by bars at the left side of the figure. The mean values of ionic constituents of tears in the figure and serum after pilocarpine injection are also given by bars at the right side of the figure. The rate of tear flow is illustrated by a histogram at 
the bottom of the figure; sample No. 1 of the histogram represents the rate of tear flow which appears spontaneously before the pilocarpine injection. It is demonstrated in the figure that the ionic concentrations of tears remain on the respective constant level irrespective of alterations in the rate of tear flow, except a slight increase in $\mathrm{K}^{+}$concentration at the increased rate of tear flow. $\mathrm{Na}^{+} \mathrm{Cl}^{+}$concentrations in tear do not differ very much from each other and $\mathrm{Na}^{+}$concentration is very close to that in serum. The mean ionic concentrations of tear and serum samples collected from several animals after pilocarpine injection are given in TABLE 1 .

TABLE 1.

The mean ionic concentrations in tear and serum. ( $\mathrm{m} \mathrm{Eq/1)}$

(The mean of five experiments)

\begin{tabular}{c|c|c|c|c|c|c|c|c|c|}
\hline & $\mathrm{Na}^{+}$ & $\mathrm{K}^{+}$ & $\begin{array}{c}\text { Total } \\
\text { cations }\end{array}$ & $\mathrm{Cl}^{-}$ & $\mathrm{HCO}_{3}^{-}$ & $\begin{array}{c}\text { Total } \\
\text { anions }\end{array}$ & $\begin{array}{c}\text { Total } \\
\text { ions }\end{array}$ & $\begin{array}{c}\text { Osmolar } \\
\text { conc. }\end{array}$ & $\mathrm{pH}$ \\
\hline Tears & $149 \mathrm{~m} \mathrm{Eq} / 1$ & 17 & 166 & 131 & 20 & 151 & 317 & 329 & 7.39 \\
\hline Serum & 146 & 4 & 150 & 111 & 22 & 133 & 283 & 312 & $7.38^{*}$ \\
\hline
\end{tabular}

* pH of arterial blood taken from Yoshimura and Fujimoto ${ }^{7}$.

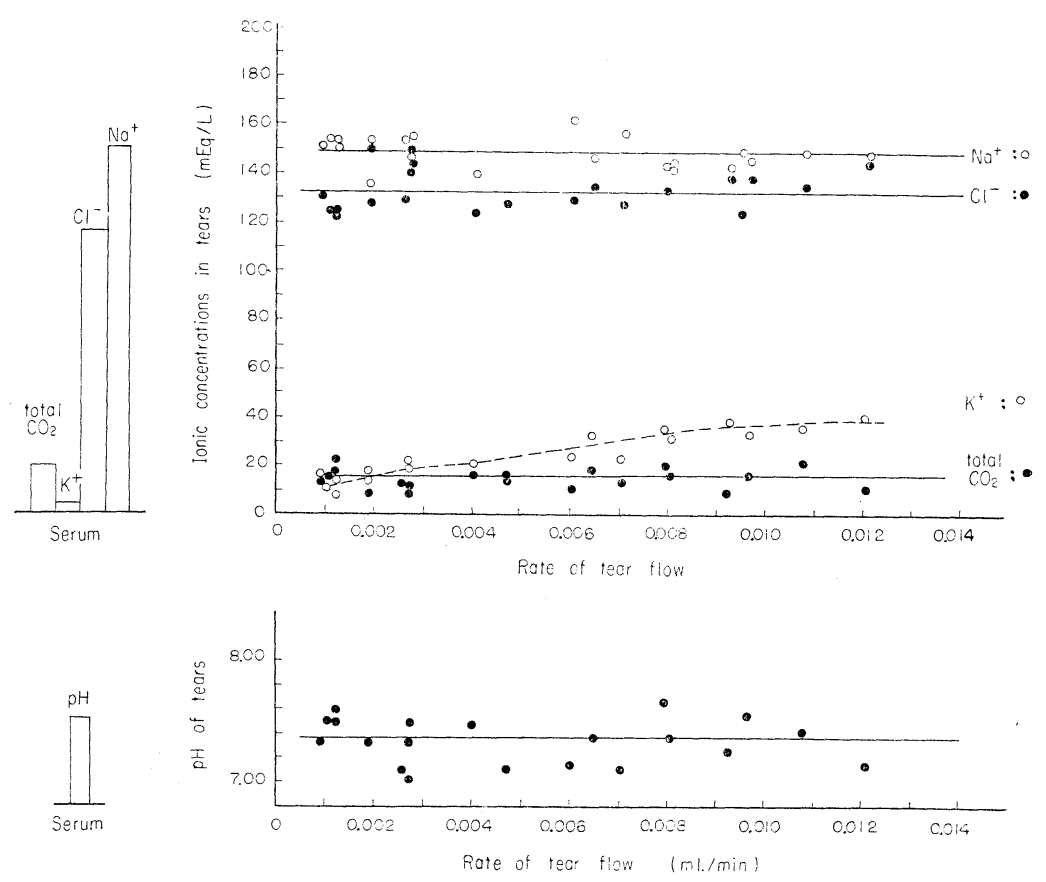

Fig. 2. Ionic concentration of tears in relation with rate of tear flow.

(The mean values of ionic concentrations in serum are shown by bars for comparison) 
The table illustrates that the total ionic concentration is slightly higher in tear than in serum and the osmolar concentration in tear is almost the same as the total ionic concentration of which the main part is occupied by $\mathrm{Na}^{+}$and $\mathrm{Cl}^{-}$concentrations. Thus the constituents which mainly contribute to the osmotic pressure in tear are those ions measured in the experiments, i. e. $\mathrm{Na}^{+}$, $\mathrm{K}^{+}, \mathrm{Cl}^{-}$, and $\mathrm{HCO}_{3}^{-}$. A slight difference in total ionic concentration between tear and serum is mainly due to that of $\mathrm{K}$-concentration and $\mathrm{Cl}$-concentration, while the concentrations of $\mathrm{Na}^{+}$and $\mathrm{HCO}_{3}{ }^{-}$are almost the same as the respective ionic concentrations in serum.

The ionic concentrations in tears measured in these experiments are plotted against the rate of tear flow in FIG. 2. It is clearly demonstrated in the figure, that the concentrations of $\mathrm{Na}^{+}, \mathrm{Cl}^{-}$and $\mathrm{HCO}_{3}^{-}$and also $\mathrm{pH}$ of tears remain constant in all the variation of rate of tear flow, while the $\mathrm{K}^{+}$concentration increases in proportion as the rate of flow increases.

2. Effects of changes in salt concentration of serum upon ionic constituents of tears. (Interrelation of ionic concentration between tears and serum.) In order to clarify the interrelation between ionic concentration in tears and that in serum, the rabbit was infused with $10 \% \mathrm{NaCl}$ or $4 \% \mathrm{KCl}$ solution to increase the $\mathrm{Na}^{+}, \mathrm{Cl}^{-}$or $\mathrm{K}^{+}$concentration in serum and changes in the ionic concentration in pilocarpine tears were examined. The rate of infusion was high $(0.07-0.14$ $\mathrm{ml} / \mathrm{Kg} / \mathrm{min}$ ) for the first hour and then reduced to about one half to maintain the constant ionic concentration in serum. After infusion of $10 \% \mathrm{NaCl}$ solution for one hour, the $\mathrm{Na}^{+}$and $\mathrm{Cl}^{-}$concentrations were raised by about $25 \mathrm{mEq} / 1$ respectively, while $\mathrm{HCO}_{3}{ }^{-}$concentration was decreased by dilution, and the $\mathrm{K}^{+}$ concentration was increased slightly, probably due to migration of $\mathrm{K}^{+}$from cells to extracellar space. About 150 minutes after the beginning of $\mathrm{NaCl}$ infusion, when the $\mathrm{Na}^{+}$and $\mathrm{Cl}^{-}$concentrations in serum had attained their respective higher constant level, pilocarpine solution was injected sebcutaneously and a copious tear flow was initiated. The concentrations of $\mathrm{Na}^{+}$and $\mathrm{Cl}^{-}$in tear were higher than the respective control value by the same extent as that of increase in serum concentration. The fact is demonstrated clearly in FIG. $3 \mathrm{~A}$, in which the $\mathrm{Na}^{+}$and $\mathrm{Cl}^{-}$concentrations in tears are plotted against the concentration of the respective ion in serum. The regression lines were drawn in the respective figure, and their equations were calculated by the method of least square, as follows:

$$
\begin{aligned}
& Y_{1}=0.997 \mathrm{X}_{1}+0.925 \ldots \ldots \ldots \ldots \ldots \ldots \text { (a) } \\
& Y_{2}=0.972 \mathrm{X}_{2}+24.95 \ldots \ldots \ldots \ldots \text { (b) }
\end{aligned}
$$

where $Y_{1}$ and $Y_{2}$ are the $\mathrm{Na}^{+}$and $\mathrm{Cl}^{-}$concentrations $(\mathrm{mEq} / 1$ ) in tears respectively, and $\mathrm{X}_{1}$ and $\mathrm{X}_{2}$ are those in serum. As the intercept constant in equation (a), i. e. 0.925 , is practically equal to zero and the regression coefficient 0.997 to 1 , this equation represents a straight line having the inclination of $45^{\circ}$ and passing, through the origin of $\mathrm{X}$ and $\mathrm{Y}$ axes. The fact indicates that the 


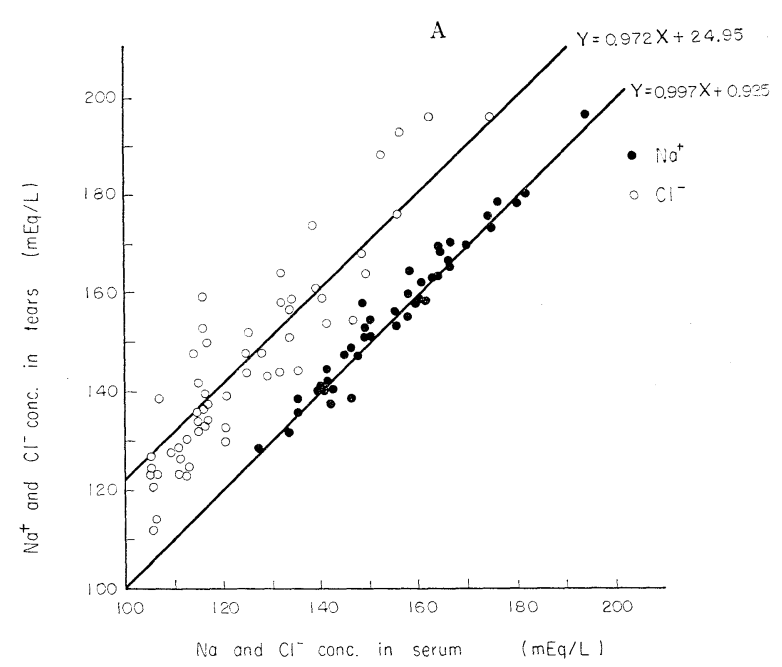

B

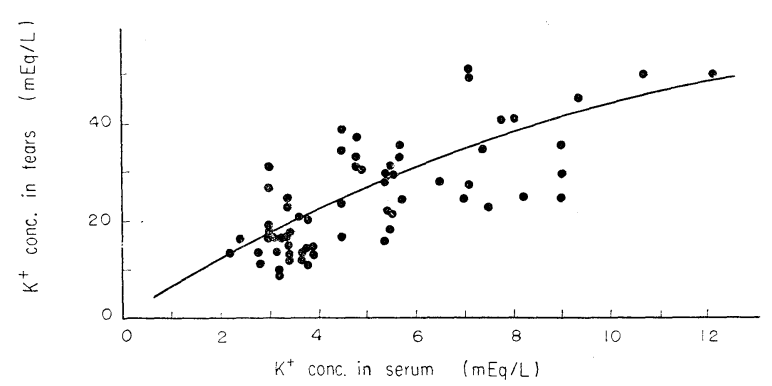

FIG. 3. Correlation between $\mathrm{Na}^{+}, \mathrm{K}^{+}$and $\mathrm{Cl}^{-}$concentrations in tears and those in serum.

$\mathrm{Na}^{+}$concentration in tears is always the same with that in serum. While the regression coefficient of the equation (b) is practically the same with 1 , the intercept constant is about 25. It follows that the $\mathrm{Cl}^{-}$concentration in tears changes in proportion to changes of that in serum, keeping the same difference between the two, i, e, $25 \mathrm{mEq} / 1$. As the $\mathrm{Cl}^{-}$concentration in normal serum is about $110 \mathrm{mEq}$, the ratio of $\mathrm{Cl}^{-}$concentration in tears to that in serum is about 1.2 , while the ratio of total ion concentration in tears to that in serum is 1.1 as shown in TABLE 1. Thus the concentration ratio of $\mathrm{Cl}^{-}$in tears to that in serum is the highest among those of the other ions.

One of the experimental results after $\mathrm{KCl}$ infusion is illustrated in FIG. 4. Pilocarpine was injected after the $\mathrm{K}^{+}$concentration in serum had attained a certain level higher than the control. The secretion of tear was stimulated and it attained a maximum value about 15 minutes after injection. 


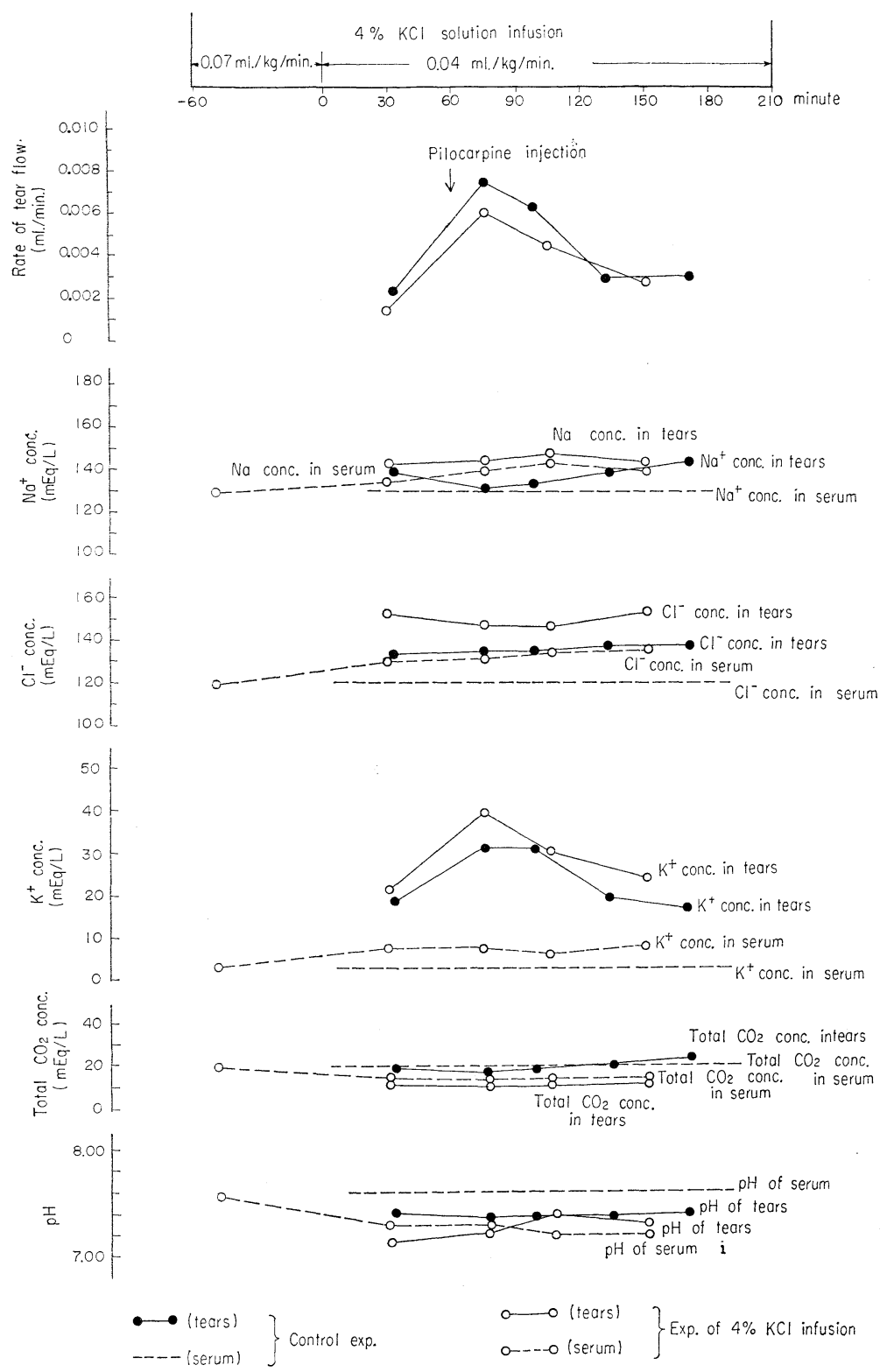

FIG. 4. Rate of tear flow and ionic concentrations in tears and in serum.

Curves in Fig. 4 demonstrated that not only the $\mathrm{K}^{+}$but also $\mathrm{Na}^{+}$and $\mathrm{Cl}^{-}$ concentrations in serum increase after $\mathrm{KCl}$ infusion, while $\mathrm{HCO}_{3}{ }^{-}$ion concentration and $\mathrm{pH}$ of serum decrease by dilution. As stated above, the concentrations of $\mathrm{Na}^{+}$and $\mathrm{Cl}^{-}$in tears change in proportion to changes of the respective 
ion concentration in serum. Thus $\mathrm{Na}^{+}$and $\mathrm{Cl}^{-}$concentrations in tears increased somewhat after $\mathrm{KCl}$ infusion, and remained at their respective constant levels irrespective of changes in the rate of tear flow.

Another experiment reveals that the concentration of $\mathrm{HCO}_{3}{ }^{-}$in tears also holds a linear relationship with that in serum of which the regression coefficient is 1 and the intercept constant is zero, and thus it is reduced slightly after $\mathrm{KCl}$ infusion in FIG. 4. As the $\mathrm{pH}$ of tear is determined by the bicarbonate concentration and $\mathrm{CO}_{2}$ partial pressure, $\mathrm{pCO}_{2}$, in tears which are equilibrated with those in serum, the $\mathrm{pH}$ of tears is almost equal to the $\mathrm{pH}$ of serum as is shown in FIG. 1 and 4 and TABLE 1 . Thus the $\mathrm{pH}$ of tears is reduced to a certain constant level after $\mathrm{KCl}$ infusion, reflecting from a reduced $\mathrm{pH}$ level in serum, as is seen in FIG. 4.

The $\mathrm{K}^{+}$concentration in tears after $\mathrm{KCl}$ infusion seems to be higher than the control, but the fact is not so clearly illustrated in FIG. 4, because the $\mathrm{K}^{+}$ concentration in tears changes parallel to changes of the rate of tear flow as is described later.

In order to examine quatitatively the interrelation between the $\mathrm{K}^{+}$concentration and the rate of the tear flow, the former was plotted against the latter in Fig. 5. Contrary to the report from THAYsen and THORN ${ }^{3)}$, the interrelation is not simple. The $\mathrm{K}^{+}$concentration in tears increases as the rate of tear flow increases until the $\mathrm{K}^{+}$concentration attains to a certain maximum level.

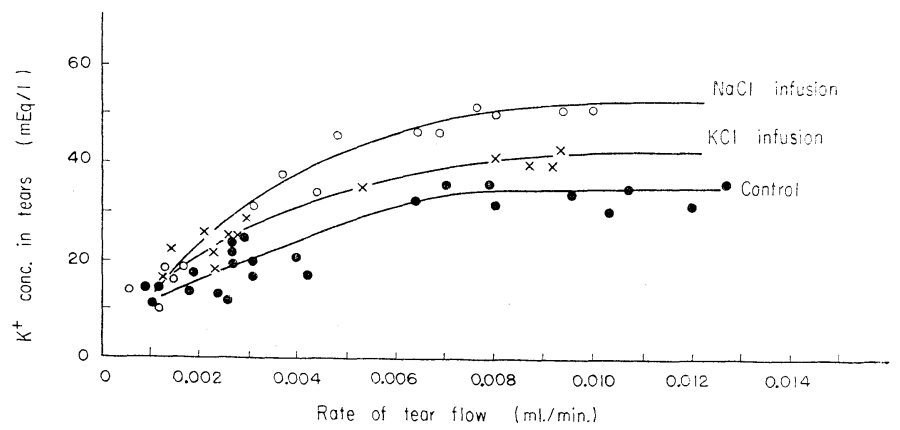

FIG. 5. Relation between concentration of $\mathrm{K}^{+}$in tears and rate of tear flow during infusion of $10 \% \mathrm{NaCl}$ and $4 \% \mathrm{KCl}$ solution.

Moreover, three different curves are drawn to fit the plots, according to the experimental conditions, i. e., the infusion of $\mathrm{NaCl}$ solution, and of $\mathrm{KCl}$ solution and the control experiment without salt infusion. The reason why the interrelation differs according to the kind of solution infused is not clear. But a part of it may be explained by the difference of $\mathrm{K}^{+}$concentration in serum, because the $\mathrm{K}^{+}$concentration in tears is strongly influenced by that in serum as is shown in FIG. 3, B. in which the $\mathrm{K}^{+}$concentration in tears at the maximum rate of tear flow is plotted against the $\mathrm{K}^{+}$concentration in serum, and 
$\mathrm{K}^{+}$concentration in serum is found to increase after $\mathrm{NaCl}$ infusion, probably owing to the migration of cellular $\mathrm{K}^{+}$in exchange of $\mathrm{Na}^{+}$which penetrates into the tissue cells.

3. Secretion potential of lacrimal gland with special reference to its salt secretion. By measuring the potential between the indifferent electrodes placed in the conjunctival sac and in the subcutaneous tissue of eye lid respectively, the resting potential of about $4-27 \mathrm{mV}$ was detected. The negative side of the potential is located in the conjunctival sac, while the subcutaneous tissue is on the positive side. The resting potential remains almost constant at least for 5 or 10 minutes, though it shows a slow drift and also large individual differences. By injecting the pilocarpine solution into the animal, the lacrimal secretion is provoked, and the potential presents a large negative change $(7-22 \mathrm{mV})$ which follows a similar time course to that of the rate of tear flow, and thus this potential change is named "the secretion potential". An example of the potential measurement is illustrated in FIG. 6. It should be pointed out here,

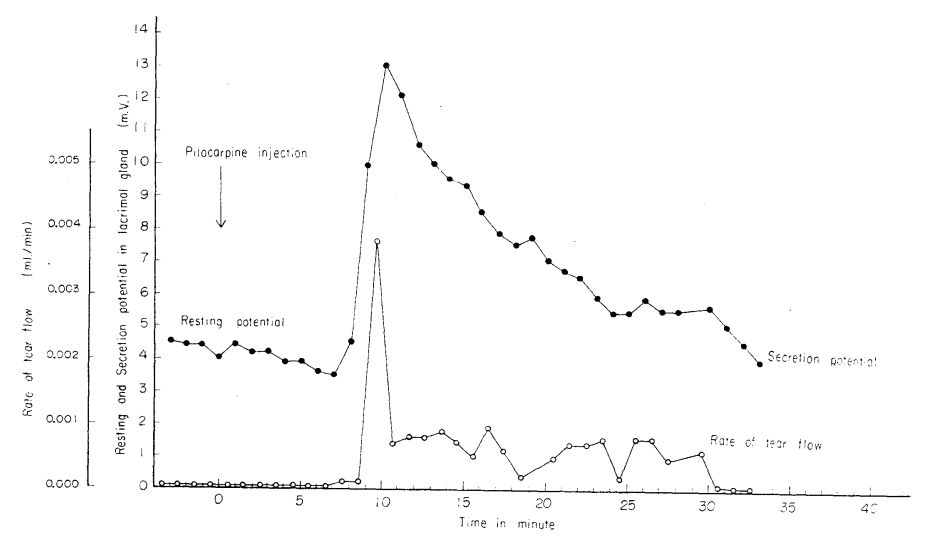

FIG. 6. Rate of tear flow and secretion potential of lacrimal gland.

that the peak of secretion potential somewhat lags behind that of the rate of tear flow. Comments on this lag of time course of secretion potential will be given later under the article of discussion.

Effects of $\mathrm{KCl}$ and $\mathrm{NaCl}$ infusion upon the secretion potential were examined. FIG. 7 is an example of the potential measurements during $\mathrm{KCl}$ infusion. The resting potential decreases after the beginning of $\mathrm{KCl}$ infusion by several millivolts, and remains almost constant at a certain low level after 4050 minutes of $\mathrm{KCl}$ infusion, when the $\mathrm{K}^{+}$concentration in serum attains at equilibrium. By injecting the pilocarpine solution, the secretion potential is provoked on this lowered resting level and changes in association with the rise of tear flow just as is seen in the control experiment without salt infusion in FIG. 6.

FIG. 8 illustrates an experiment in which effects of infusion of $10 \% \mathrm{NaCl}$ 


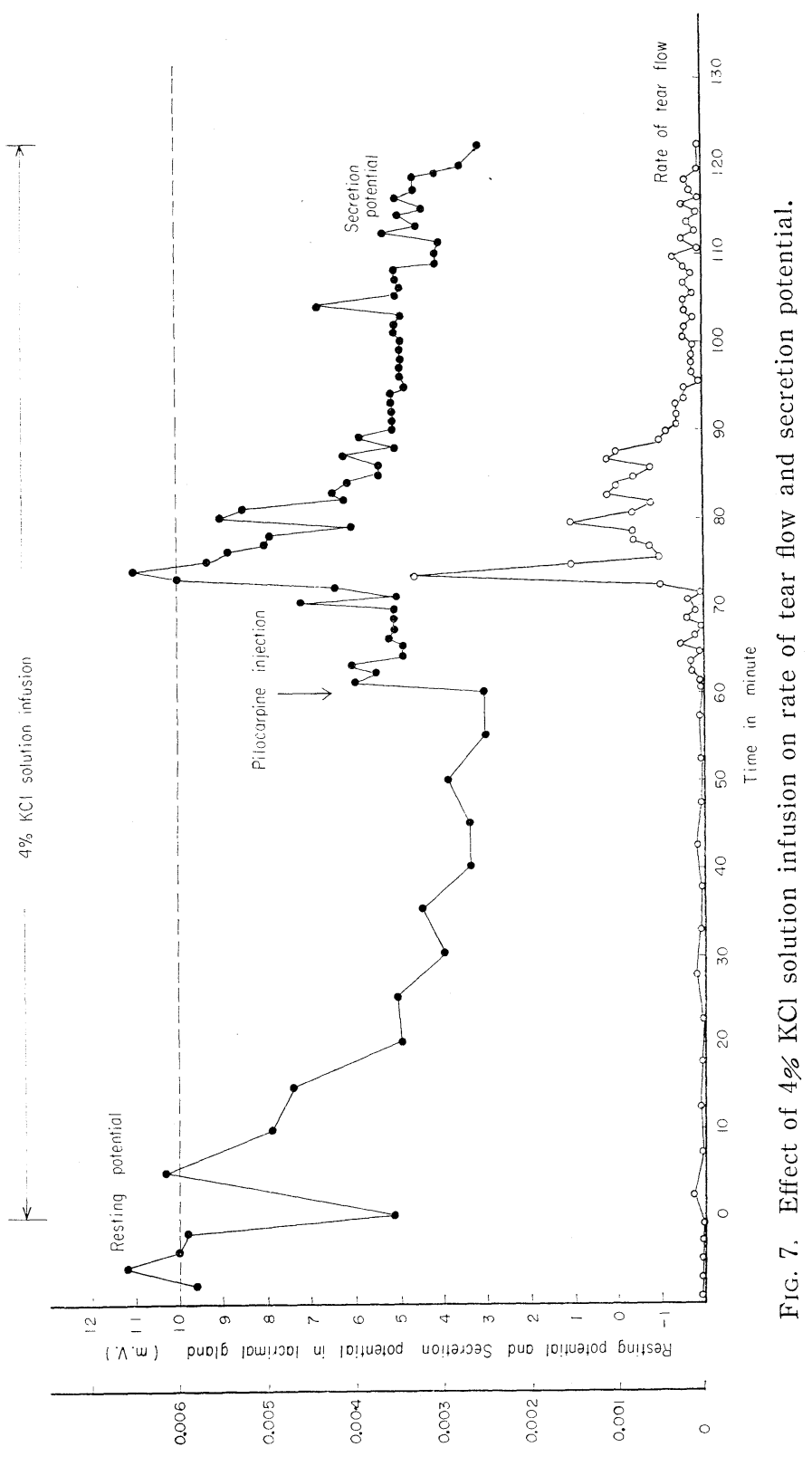

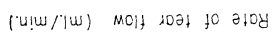

solution upon the secretion potential were observed. The secretion potential was provoked by a pilocarpine injection at the beginning. The injection was repeated to maintain the secretion potential at a constant level. After an equilibration was attained, the infusion of $10 \% \mathrm{NaCl}$ solution was performed. 


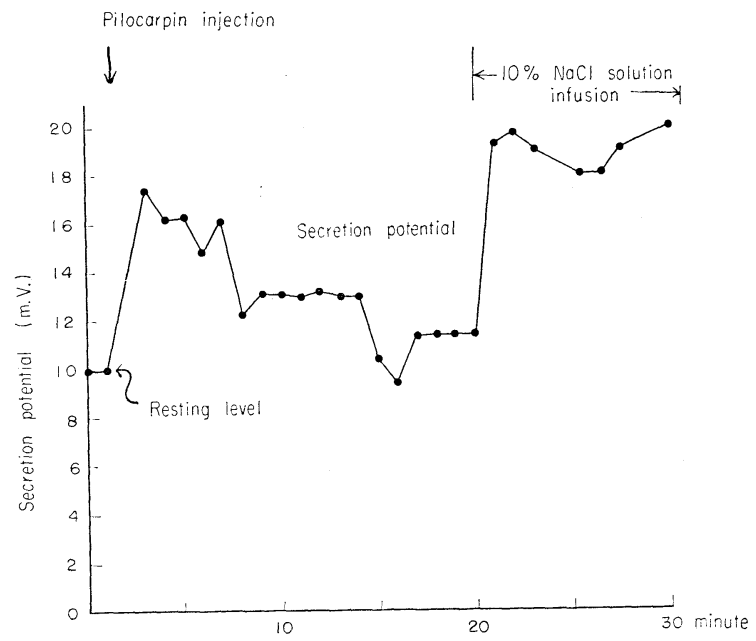

FIG. 8. Effect of $10 \% \mathrm{NaCl}$ solution infusion on the secretion potential.

The potential showed a large increase of about $10 \mathrm{mV}$. Effect of $\mathrm{NaCl}$ infusion upon the resting potential was examined in another experiment. The potential was changed by the salt infusion, but the direction and the magnitude of the change varied from experiment to experiment and no consistent results could be obtained. When the resting potential was decreased, the $\mathrm{K}^{+}$concentration in serum was verified to have been increased after $\mathrm{NaCl}$ infusion, probably due to an exchange of extracellular $\mathrm{Na}^{+}$with the intracellular $\mathrm{K}^{+}$, while it increased when the $\mathrm{K}^{+}$concentration in serum was decreased by dilution, and the $\mathrm{Cl}^{-}$ concentration was increased by infusion of $\mathrm{NaCl}$ solution.

\section{DISCUSSION}

From the above experimental results, the mechanism of tear flow or of water and salt secretion from lacrimal gland will be discussed. First of all, it should be mentioned here that the $\mathrm{Cl}^{-}$concentration in tears is always higher by about $25 \mathrm{mEq}$ than that in serum, but remains almost constant irrespective of the rate of tear flow, while $\mathrm{Na}^{+}$and $\mathrm{HCO}_{3}{ }^{-}$concentrations are always equal to those in serum. The fact suggests that the lacrimal gland may secrete $\mathrm{Cl}^{-}$ actively and $\mathrm{Na}^{+}$passively, and the $\mathrm{NaCl}$ thus secreted may initiate the passive transport of water. This suggestion is supported further by the fact that the rate of tear flow accompanies the increase of negative potential in the luminal side of lacrimal gland.

In order to discuss this suggestion more quantitatively, the interrelation between the rate of ionic secretion and the rate of tear flow is illustrated graphically in FIG. 9 and 10 . The rate of ionic secretion was calculated by multiplying the ionic concentration by the rate of tear flow. FIG. 9 presents 


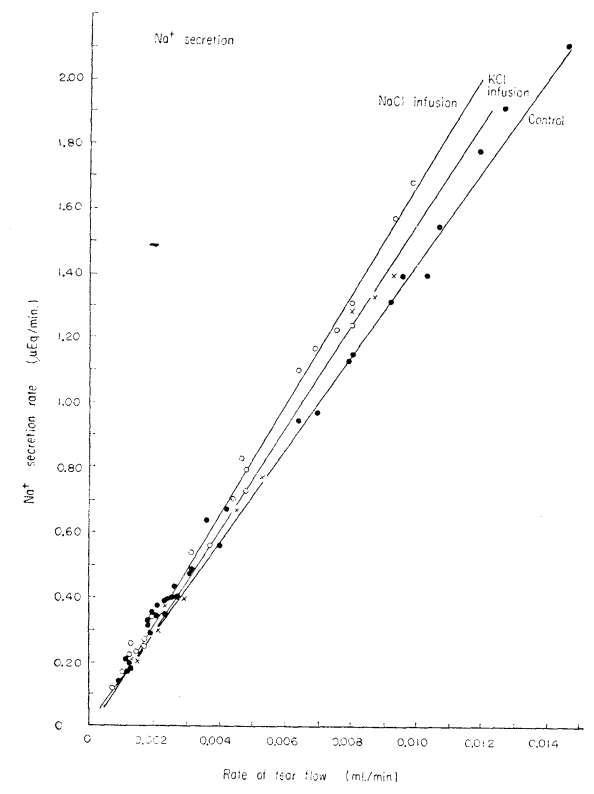

FIG. 9. Relation between rate of tear flow and rate of ionic secretion from lacrimal grand.

TABLE 2.

Regression lines of correlation between the rate of ionic secretion and the rate of tear flow.

\begin{tabular}{|c|c|c|c|c|c|}
\hline \multirow{2}{*}{ Ion } & \multirow{2}{*}{$\begin{array}{l}\text { Experimental } \\
\text { condition }\end{array}$} & \multirow{2}{*}{ Regression line } & \multicolumn{2}{|c|}{ Notation of } & \multirow{2}{*}{$\begin{array}{c}\text { Ionic } \\
\text { concentration } \\
\text { in serum } \\
(\mathrm{mEq} / \mathrm{L})\end{array}$} \\
\hline & & & $\mathrm{X}$ & $\mathrm{Y}$ & \\
\hline $\mathrm{Na} \div$ & $\begin{array}{l}\text { Control } \\
\mathrm{KCl} \text { infusion } \\
\mathrm{NaCl} \text { infusion }\end{array}$ & $\begin{array}{l}Y=140.4 \times-0.04 \\
Y=154.1 \times-0.01 \\
Y=166.2 \times-0.003\end{array}$ & $\begin{array}{l}\text { Rate of } \\
\text { tear flow } \\
(\mathrm{ml} / \mathrm{min} .)\end{array}$ & $\begin{array}{l}\text { Rate of } \mathrm{Na} \\
\text { secretion } \\
(\mu \mathrm{Eq} / \mathrm{min} .)\end{array}$ & $\begin{array}{l}{\left[\mathrm{Na}^{+}\right]} \\
146.2 \\
149.6 \\
167.8\end{array}$ \\
\hline $\mathrm{HCO}_{3}^{-}$ & $\begin{array}{l}\text { Control } \\
\mathrm{KCl} \text { infusion } \\
\mathrm{NaCl} \text { infusion }\end{array}$ & $\begin{array}{l}Y=20.9 \times-0.02 \\
Y=16.3 \times-0.01 \\
Y=12.0 \times+0.01\end{array}$ & Ditto & $\begin{array}{l}\text { Rate of } \\
\mathrm{HCO}_{3} \\
\text { secretion } \\
\text { ( } \mu \mathrm{Eq} / \mathrm{min} .)\end{array}$ & $\begin{array}{c}{\left[\mathrm{HCO}_{3}^{-}\right]} \\
23.2 \\
17.4 \\
13.2\end{array}$ \\
\hline $\mathrm{Cl}^{-}$ & $\begin{array}{l}\text { Control } \\
\mathrm{KCl} \text { infusion } \\
\mathrm{NaCl} \text { infusion }\end{array}$ & $\begin{array}{l}Y=1.01 \times+2.15 \\
Y=1.01 \times+2.21 \\
Y=1.05 \times+2.35\end{array}$ & $\begin{array}{l}\text { Logarithm } \\
\text { of the rate } \\
\text { of tear flow } \\
\text { ( } \mathrm{ml} / \mathrm{min} \text {.) }\end{array}$ & $\begin{array}{l}\text { Logarithm } \\
\text { of the rate } \\
\text { of } \mathrm{Cl} \\
\text { secretion } \\
\text { ( } \mu \mathrm{Eq} / \mathrm{min} .)\end{array}$ & $\begin{array}{l}{\left[\mathrm{Cl}^{-}\right]} \\
110.1 \\
127.9 \\
144.4\end{array}$ \\
\hline $\mathrm{K}^{+}$ & $\begin{array}{l}\text { Control } \\
\mathrm{KCl} \text { infusion } \\
\mathrm{NaCl} \text { infusion }\end{array}$ & $\begin{array}{l}Y=1.38 \times+2.36 \\
Y=1.44 \times+2.51 \\
Y=1.51 \times+2.77\end{array}$ & Ditto & $\begin{array}{l}\text { Logarithm } \\
\text { of the rate } \\
\text { of } \mathrm{K} \\
\text { secretion } \\
\text { ( } \mu \mathrm{Eq} / \mathrm{min} .)\end{array}$ & $\begin{array}{c}{[\mathrm{K} \div]} \\
3.9 \\
6.7 \\
6.0\end{array}$ \\
\hline
\end{tabular}


the graph for the $\mathrm{Na}$ secretion, while FIG. 10 graphs for the $\mathrm{Cl}$ and $\mathrm{K}$ secretion. It is demonstrated in Fig. 9, that the rate of $\mathrm{Na}$ secretion bears a linear relationship with the rate of tear flow, though the interrelation differs according to the experimental condition, i.e. whether the salt solution is infused or not. Equations of regression lines of the correlation calculated by the method of least square are given in TABLE 2. As the intercept constant of the equation for $\mathrm{Na}$ secretion is practically equal to zero in all experimental conditions, the equations represent the straight lines which pass the origin. As the rate
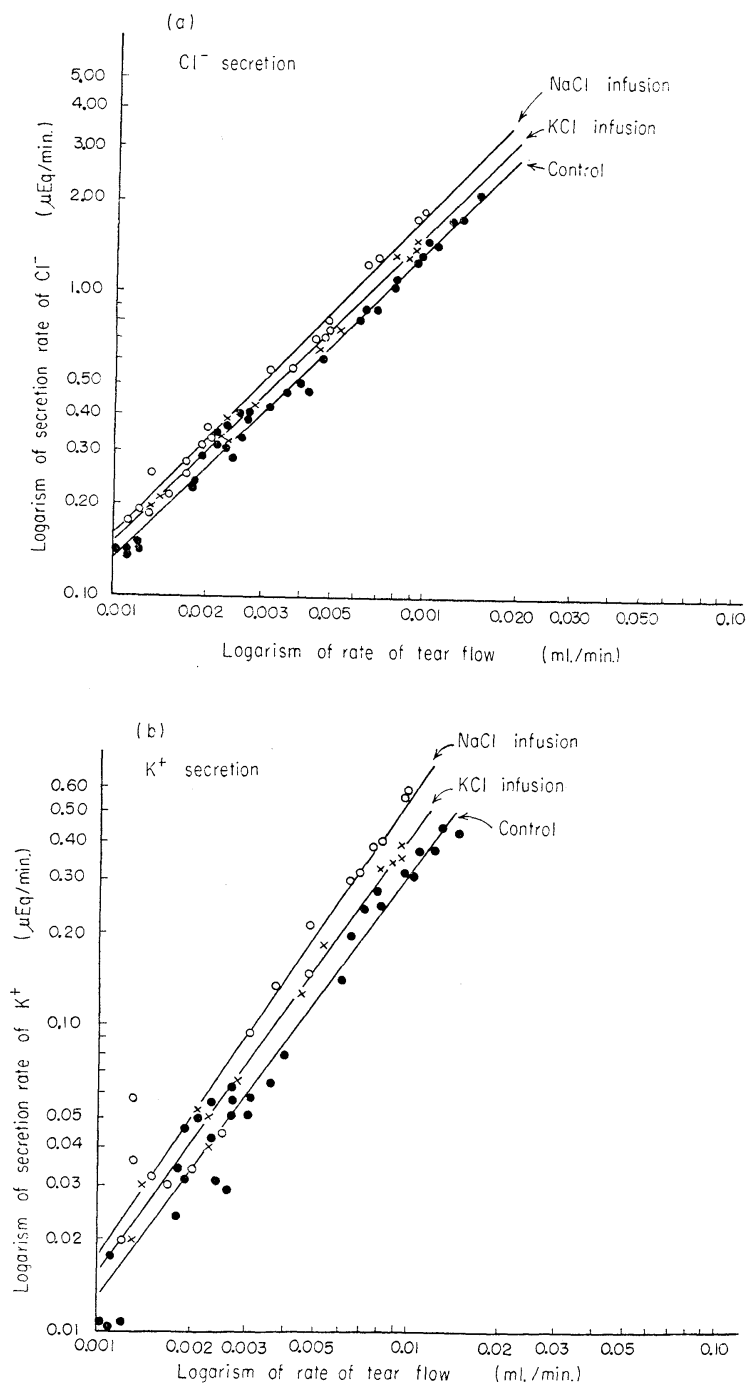

FIG. 10. Logarithmic relation between rate of tear flow and rate of ionic secretion. 
of ionic secretion in tears, $\mathrm{Y}$, is to be given by multiplying the ionic concentration by the rate of tear flow, $\mathrm{X}$, the regression coefficient of the straight line corresponds to the ionic concentration in tears. It is demonstrated in TABLE 2 that the $\mathrm{Na}^{+}$concentration in tears is almost the same as that in serum, as already shown in FIG. 3. It follows that the alteration of the interrelation of the rate of $\mathrm{Na}^{+}$secretion with reference to the rate of tear flow according to the experimental condition is explicable as due to the difference of $\mathrm{Na}^{+}$concentration in serum. All of these facts support the view of passive secretion of $\mathrm{Na}^{+}$in tears. The $\mathrm{HCO}_{3}^{-}$secretion can also similarily be explained as passive secretion, while that of $\mathrm{Cl}^{-}$as well as of $\mathrm{K}^{+}$is quite differently related with the rate of tear flow. No linear relation can exist between the two but the relation is exponential. Thus the logarithm of the rate of tear flow was plotted against the logarithm of the rate of ionic secretion in FIG. $10 \mathrm{a}$ and b. FIG. $10 \mathrm{a}$ is the figure for $\mathrm{Cl}^{-}$secretion, while FIG. $10 \mathrm{~b}$ is that for $\mathrm{K}^{+}$ secretion. It is clearly demonstrated in the figure that the relation is rectilinear, and thus the equation of regression line was calculated by the method of least square for $\mathrm{Cl}^{-}$and $\mathrm{K}^{+}$secretion and is illustrated in TABLE 2. The equations are different according to the experimental conditions. The logarithmic relationship between the rate of ionic secretion and that of tear flow can be explained as follows:

If the water secretion from the lacrimal gland follows the active secretion of a certain ion, the increasing rate of ionic secretion in the unit time should be linearly related with the rate of increase of tear flow. Consequently, the following differential equation can be derived, where $m$ is the rate of the ionic secretion, $\mathrm{V}$ that of tear flow and $\mathrm{k}$ is a proportional constant:

Integrating this equation,

$$
\mathrm{dm} / \mathrm{m}=\mathrm{kdV} / \mathrm{V}
$$

$$
\log \mathrm{m}=\mathrm{k} \log \mathrm{V}+\mathrm{C},
$$

Where $\mathrm{C}$ is the integration constant. This is the theoretical logarithmic relation between the rate of ionic secretion and that of tear flow on the above premise.

For the case of $\mathrm{Cl}^{-}$secretion, TABLE 2 indicates that the constant $\mathrm{k}$ is approximately 1 , and that it is about 1.5 for $\mathrm{K}^{+}$secretion. Thus the fact that the water secretion of lacrimal gland accompanies the secretion of $\mathrm{Cl}$ with one and the same rate is verified by this analysis. From the above equation, it is deduced that $\mathrm{C}$ in the equation for the case of $\mathrm{Cl}^{-}$secretion corresponds to the logarithm of the concentration of $\mathrm{Cl}^{-}$in tears, which is very close to that in serum. The cause of the alteration of regression line according to the experimental condition can, thus, be explained as mainly due to the alteration of serum $\mathrm{Cl}^{-}$concentration, as is indicated in TABLE 2 .

For the case of $\mathrm{K}^{+}$secretion, the constant, $\mathrm{k}$, is not 1.0 , but about 1.5 . 
The fact indicates that the rate of increase of $\mathrm{K}^{+}$secretion is higher than that of water secretion from the gland. Thus the $\mathrm{K}^{+}$concentration in tear should increase as the rate of tear flow increases, as was already mentioned in FIG. 4 and 5. These facts suggest strongly the active secretion of $\mathrm{K}^{+}$from the lacrimal gland.

Observations of secretion potential further support the views obtained from the measurements of ionic constituents of tears in relation to the rate of tear flow.

In the last part of the experimental results, it was pointed out that the secretion potential changes, following the time course of the rate of tear flow. As the potential is negative at the luminal side of the gland, the secretion potential is explicable as due to the active transport of $\mathrm{Cl}^{-}$which exerts an electrostatic attraction upon the cation, especially $\mathrm{Na}^{+}$. The fact that the total osmolar concentration of tear is very close to that of serum, while $\mathrm{Cl}^{-}$concentration is always higher in tears than in serum, is also explicable on the basis that the transport of $\mathrm{NaCl}$ through the gland cells initiates osmotic flow of water from the lacrimal gland. A more direct evidence for the negative secretion potential due to $\mathrm{Cl}^{-}$transport is the fact mentioned in FIG. 8, in which the secretion potential was increased by promoting $\mathrm{Cl}^{-}$tranport by the infusion of $10 \% \mathrm{NaCl}$ solution. The fact that the peak of secretion potential lags somewhat behind the peak of tear flow can also be explained by the postulation of the active transport of $\mathrm{K}^{+}$which is to be initiated by the secretion stimulus of lacrimal gland.

Since the active transport of $\mathrm{K}^{+}$may cause a positive potential through the gland cells, the rise of negative potential due to $\mathrm{Cl}^{-}$transport at the initiation of tear flow may be damped by the counter potential due to $\mathrm{K}^{+}$transport, and thus the peak of the secretion potential apparently lags behind the peak of tear flow which accompanies the transport of $\mathrm{Cl}^{-}$. Another evidence for the active transport of $\mathrm{K}^{+}$is a close relationship of its secretion with the rate of tear flow, i.e. the secretory activity of the lacrimal gland, as already pointed out.

\section{SUMMARIES}

By stimulating the lacrimal gland of rabbit with pilocarpine, the tears were collected through the fistula inserted into the nasolacrimal duct, and the ionic composition was analysed with special reference to the rate of lacrimal flow, and the ionic concentrations in serum. The secretion potential was also measured with reference to the secretion of ions in tears. Results obtained are as follows:

1. The osmolarity of tears is mainly produced by salts which are mainly composed of $\mathrm{Na}^{+}$and $\mathrm{Cl}^{-}$and partly of $\mathrm{K}^{+}$and $\mathrm{HCO}_{3}^{-}$and is kept almost con- 
stant at a slightly higher level than that of serum, irrespective of the rate of tear flow. The concentrations of $\mathrm{Na}^{+}, \mathrm{HCO}_{3}{ }^{-}$and $\mathrm{Cl}^{-}$in tears are all kept constant, irrespective of the rate of tear flow, while the $\mathrm{K}^{+}$concentration changes parallel to changes of the rate of tear flow.

2. The concentrations of $\mathrm{Na}^{+}$and $\mathrm{HCO}_{3}{ }^{-}$in tears are approximately the same as that of the respective ion in serum even when the concentration in serum is changed by salt infusion, while $\mathrm{K}^{+}$and $\mathrm{Cl}^{-}$concentrations are always higher in tears than in serum. The $\mathrm{Cl}^{-}$concentration in tears bears a linear relation with that in serum of which the regression coefficient is 1 and the intercept constant is about $25 \mathrm{mEq}$. The $\mathrm{pH}$ of tears is approximately the same as the serum $\mathrm{pH}$ and is determined by $\mathrm{HCO}_{3}{ }^{-}$concentration and $\mathrm{CO}_{2}$ partial pressure which equilibrate with those in serum.

3. The potential being measured by external leading from the luminal side and the outside of the lacrimal gland, a resting potential of about $4-27 \mathrm{mV}$ was detected. The negative side of the potential is in the lumen of gland. The negativity of the potential in the luminal side increases as the rate of tear flow is increased by stimulation of lacrimal gland, and thus the secretion potential of about $7-22 \mathrm{mV}$ appears. The secretion potential runs parallel to the time course of the rate of tear flow, though the peak of the former somewhat lags behind that of the latter.

4. The increase of the resting potential as well as the secretion potential was provoked by raising the $\mathrm{Cl}^{-}$concentration in serum by $\mathrm{NaCl}$ infusion. The changes of potential may be due to the acceleration of $\mathrm{Cl}^{-}$secretion. On the other hand, the potential was reduced after $\mathrm{KCl}$ infusion, probably owing to the promotion of $\mathrm{K}^{+}$secretion by a rise of serum $\mathrm{K}^{+}$concentration.

5. From the above results and analysis of the interrelation between the rate of tear flow and the rate of ionic secretion as well as the secretion potential, it was deduced that the secretion potential as well as the water secretion (tear flow) of the lacrimal gland is associated with the active secretion of $\mathrm{Cl}^{-}$through the lacrimal gland cells, while $\mathrm{Na}^{+}, \mathrm{HCO}_{3}^{-}$are all transported passively in equilibration with those in serum. The $\mathrm{K}^{+}$secretion is also an active process and affects the secretion potential to decrease.

\section{REFERENCE}

1) Krogh, A. Osmotic Regulation, London: 211, 1938.

2) Krogh, A. Lund, C. G. And Pedersen-Bjergaard, K. Acta Physiol. Skand. 10:88, 1954.

3) Thaysen, J.H. and Thorn, N.A. Amr. J. Physiol. 178: 160, 1954.

4) Yoshimura, H. And Hosokawa, K. J. Physiol. Soc. Jap. 19: 809, 1957 (Japanese).

5) Natelson, S. Am. J. Clin. Path. $21: 1153,1951$.

6) Uragami, Y. and Yoshimura, H. Biochemistry, $30: 515,1958$ (Japanese).

7) Yoshimura, H. And Fujimoto, T. J. Biochem. 25: 493, 1937. 